Pamiętnik Literacki 2017, 1, s. 135-148
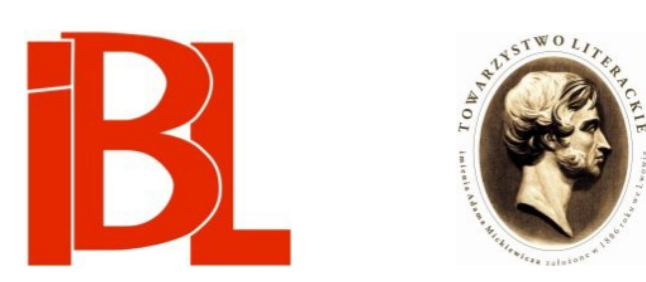

Nieukończony doktorat Tadeusza

Micińskiego o nieśmiertelności duszy w

filozofii Platona

Tomasz Mróz 


\section{NIEUKOŃCZONY DOKTORAT TADEUSZA MICIŃSKIEGO O NIEŚMIERTELNOŚCI DUSZY W FILOZOFII PLATONA}

Najważniejszym źródłowym materiałem dla niniejszego tekstu jest nieukończona i pozostawiona w rękopisie rozprawa naukowa Tadeusza Micińskiego, który zamierzał sfinalizować swoje starania o stopień doktorski pod kierunkiem najbardziej znanego wówczas na świecie polskiego historyka filozofii, Wincentego Lutosławskiego. Cel artykułu stanowi ukazanie przyczyn, jakie pchnęły początkującego poetę do podjęcia wysiłku napisania dysertacji, zarysowanie przebiegu tych prac oraz naświetlenie powodów ich przerwania i ostatecznego zaniechania.

Początek znajomości z Lutosławskim, której skutek stanowiło - jak się okaże - głębsze zainteresowanie się Micińskiego Platonem, wiąże się najprawdopodobniej ze spotkaniem, które miało miejsce w 1896 r. w Lipsku, gdzie Miciński studiował. Zapewne zwrócił na siebie uwagę przebywającego tam filozofa, angażował się bowiem w działalność narodową i przewyższał zdolnościami większość uczęszczających na tamtejszy uniwersytet Polaków ${ }^{1}$. Niebawem został zaproszony przez Lutosławskiego do Hiszpanii, gdzie przyjechał rok później². Zapewne było to dla Micińskiego niezwykle istotne, najwyraźniej widział on w kontynuowaniu tej znajomości nowe perspektywy dla własnego rozwoju, skoro $\mathrm{z}$ tego powodu przerwał studia ${ }^{3}$. Wizyta u Lutosławskich w okolicach La Corunii wiosną 1897 musiała utwierdzić go w przekonaniu o słuszności tej decyzji, jak pisze Jerzy Illg:

pierwszy pobyt, prócz wrażeń turystycznych i urzeczenia pięknem skalistej nadmorskiej przyrody, przyniósł zawarcie bliższej i wolnej jeszcze od jakichkolwiek dysonansów znajomości z filozofem, długie, zasadnicze rozmowy, inspiracje do badań nad Platonem i Towiańskim ${ }^{4}$.

Drugi przyjazd Micińskiego do Lutosławskich (w grudniu 1897), jego późniejsze spotkanie się tam ze Stanisławem i Dagny Przybyszewskimi były brzemiennymi

1 Zob. S. Pi goń, Niesamowite spotkanie literackie. Tadeusz Miciński-Wincenty Lutosławski. W: Miłe życia drobiazgi. Pokłosie. Warszawa 1964, s. 405-408. A. Gó r s k i (Tadeusz Miciński w Krakowie 〈1895-1901〉. W zb.: Miscellanea literackie 1864-1910. Red. S. Pi goń. Wrocław 1957, s. 425) podaje, że Lutosławski z Micińskim poznali się w Berlinie.

2 Zob. W. Lu to sła w s ki, Jeden łatwy żywot. Kraków 1994, s. 230.

3 Zob. J. Illg, Niesamowitego spotkania karty nieznane. Korespondencja Tadeusza Micińskiego z Wincentym Lutosławskim. W zb.: Studia o Tadeuszu Micińskim. Red. M. Pod raza - Kw i a tkows ka. Kraków 1979, s. 343. Zob. też Górski (op. cit., s. 425): „ten magnes [tj. znajomość z Lutosławskim] okazuje się teraz mocniejszy".

$4 \quad$ Illg, op. cit., s. 349. 
w skutki wydarzeniami na młodopolskim horyzoncie kulturalnym i doczekały się już szeregu opracowań ${ }^{5}$. Być może, Lutosławski zamierzał stać się dla nich wszystkich Platonem w tej swoistej Akademii ${ }^{6}$. Dla nas najważniejsze jednak, że wtedy Miciński podjął decyzję o rozpoczęciu pod kierunkiem gospodarza pracy nad doktoratem poświęconym Platonowi. Temat rozprawy wydawał się oczywisty w świetle ówczesnych zainteresowań i publikacji filozofa. Spotkanie z Lutosławskim miało dla Micińskiego także szereg innych konsekwencji - światopoglądowych, literackich i życiowych, gdyż właśnie u Lutosławskich w Hiszpanii poeta spotkał swoją żonę ${ }^{7}$.

Miciński był początkowo zafascynowany Lutosławskim. Bardzo prawdopodobne, iż przyczyną tego zainteresowania było odrzucenie kierunków filozoficznych, z którymi Miciński zetknął się podczas edukacji w Warszawie na początku lat dziewięćdziesiątych XIX wieku. Jako uczeń V Gimnazjum korzystał bowiem z wykładów Uniwersytetu Latającego, na których m.in. Adam Mahrburg i Ludwik Krzywicki przedstawiali idee postępu i rozwoju w duchu pozytywizmu8:

Chociaż [...] w tajnej „szkole” pozytywistycznej czyniono wszystko, aby utrzymać adeptów przy ostrożnej, „realistycznej” analizie ametafizycznej, nie powiodło się zachować młodzież z dala od tęsknot metafizycznych ${ }^{9}$.

Być może, nawet dlatego metafizyka - myśl Lutosławskiego, a następnie Platona - wydawała się Micińskiemu w pewnym momencie tym bardziej pociagająca. W pracach Lutosławskiego nad Platonem ze ścisłością matematyczna - w postaci stylometrycznej, statystyczno-językowej podstawy - łączyły się ambicje metafizyczne, maksymalistyczne, obce środowisku warszawskiemu, które pierwotnie współkształtowało poszukiwania intelektualne Micińskiego. Wpływ pozytywistów był na tyle silny, że nawet zapisując się na różne wykłady i zajęcia na Uniwersytecie Jagiellońskim w latach 1893-1895, pozostał wierny wyrobionym w Warszawie zainteresowaniom ${ }^{10}$. Kiedy jednak znalazł się w Lipsku, nie poświęcił już wiele czasu

5 Zestawienie wniosków z licznych - wykorzystanych w niniejszym artykule - badań dotyczących hiszpańskiego spotkania Lutosławskiego z Micińskim zob. praca T. M r o z a Wincenty Lutosławski 1863-1954. Jestem obywatelem Utopii (Kraków 2008, s. 100-106). Warto dodać, że spotkanie filozofa z Micińskim stało się dodatkowo inspiracją dla J. S o s now skiego w powieści Prąd zatokowy (Warszawa 2003).

6 Zob. J. S o s now s ki, Młodopolskie „komuny”. W zb.: Stulecie Młodej Polski. Studia. Red. M. P o draza-Kwiatkows ka. Kraków 1995, s. 41-42.

7 Zob. I11g, op. cit., s. 343. Niewątpliwie pobyty u Lutosławskich wpłynęły na zainteresowanie Micińskiego hiszpańską literaturą, kulturą i językiem, o czym pisała M. Strzałkowa (Miciński i literatura hiszpańska. „Kwartalnik Neofilologiczny” 1975, nr 2), minimalizując ich znaczenie, jak i wartość przekładów dokonywanych przez poetę. Zob. też P. S o bolc zy k, Tadeusza Micińskiego podróż do Hiszpanii. Toruń 2005.

8 Zob. J. Ty ne cki, Miciński w „szkole” Mahrburga. „Prace Polonistyczne” 1970, s. $196-197$.

9 Ibidem, s. 198. Ty n e cki (op. cit., s. 199-200) wyraził opinię, że jedną z form spełnienia owych „tęsknot maksymalistycznych” wśród młodzieży był socjalizm, a „dzieje maksymalizmu metafizycznego Micińskiego [...] moga ostrzegać, jak znikomym remedium przeciw irracjonalizmowi jest fenomenalistyczna analityka pozytywizmu” (s. 201).

10 J. Ty n e cki, Kraków i Polesie. Krakowskie studia (1893-1895) Tadeusza Micińskiego w świetle jego korespondencji. „Prace Polonistyczne” 1972, s. 146. Zob. też s. 136-137. Na marginesie warto zwrócić uwage na metodologię badań historycznoliterackich J. Ty n e c k i e go (Inicjacje mistyka. Rzecz o Tadeuszu Micińskim. Łódź 1976, s. 127, zob. też s. 5-11, 265-268), poddającego kry- 
na systematyczne, książkowe studia, gdyż wtedy najwyraźniej „egzotyka mistycyzmu [...] zdaje się go już przyzywać"11.

W trakcie studiów krakowskich - przeciwnie, niż można by się spodziewać Miciński nie skorzystał z wykładów z filozofii greckiej. Wybór przedmiotów studiów ewoluował od początkowego ukierunkowania historycznego ku filologicznemu. Najodpowiedniejsze byłyby dla Micińskiego wykłady z historii filozofii greckiej, prowadzone wówczas erudycyjnie przez Stefana Pawlickiego, na nie jednak nie uczęszczał. Słuchał natomiast wykładów Pawlickiego z filozofii współczesnej, filozofii polskiej oraz $\mathrm{z}$ teologii. Z filozofią zapoznawał się także na wykładach Maurycego Straszewskiego $z$ teorii wiedzy i na jego konwersatorium filozoficznym. Jednak w kontekście przyszłych prac nad Platonem najważniejszy był udział Micińskiego w seminarium greckim Kazimierza Morawskiego ${ }^{12}$. Zajęcia te zasadniczo Micińskiego rozczarowały, jak pisał w liście: „Ja sam czuję to doskonale, że jestem na drodze niewłaściwej, ale w tutejszym uniwersytecie trudno iść w kierunku innym [...]"13. Przegląd jego kursów potwierdza, że zainteresowanie Platonem musiało być konsekwencją spotkania $z$ Lutosławskim ${ }^{14}$.

Jak słusznie zauważył Stanisław Pigoń:

Lutosławski zetknąwszy się z Micińskim dostrzegł w nim zaraz indywidualność pokrewną, a tak bogato uposażoną. $Z$ drugiej strony rozumiemy też, że i młody literat entuzjasta nie został obojętny na takie wyróżnienie znakomitego, na miarę europejską zapowiadającego się filozofa ${ }^{15}$.

Poeta przyjął wobec Lutosławskiego postawę ucznia, deklarował w listach: „swa przyszłą działalność literacką chcę oprzeć na wyrobionej myśli filozoficznej. Specjalnie interesuje mnie Platon, którego większą część dzieł czytałem po grecku"16. Postanowienie nadrobienia lektury Platona nie mogło szybko dojść do skutku, gdyż „dziwnie liczne obowiązki odciaggaja go [tj. Micińskiego] od tego zadania”17. Zanim poeta dotarł do Hiszpanii, zajął się Towiańskim, następnie dołożył do tego dzieła Cieszkowskiego i Hoene-Wrońskiego, solennie zapewniając w listach do swego mistrza, że po ukończeniu kolejnego zadania, tzn. biografii Mickiewicza, natychmiast poświęci się Platonowi ${ }^{18}$. Wreszcie po dłuższym milczeniu Miciński wyznał:

tyce metodę ergocentryczną, polegającą na oddzieleniu biografistyki - jako nie będącej pomocną w zrozumieniu dzieł - od badań nad literaturą. Wydaje się, że podobny problem metodologiczny towarzyszy nawet częściej pracom historycznofilozoficznym.

11 Tynecki, Kraków i Polesie, s. 146.

12 Zob. Ty necki, Inicjacje mistyka, s. 251-256.

13 T. Miciński, list do J. Lewandowskiej, z 13 XII 1983. Cyt. za: Tynecki, Inicjacje mistyka, s. 254.

14 Zob. Ty necki, Inicjacje mistyka, s. 308, przypis 289.

15 Pigoń, op. cit., s. 408.

16 Listy Tadeusza Micińskiego do Wincentego Lutosławskiego z lat 1897-1914. W zb.: Studia o Tadeuszu Micińskim, s. 365 (list nr 1, z 9 II 1897). Na kartach korespondencji otrzymywanej od Micińskiego Lutosławski czynił dopiski (co podają edytorzy), np. tu po słowie „większą” zanotował nieco ironicznie „potem się okazało, że tylko 4 dialogi” (ibidem, s. 365).

17 J. S o s now s ki, Playa de Mera. Jeszcze o „niesamowitym spotkaniu literackim”. „Kresy” 1998, nr 1, s. 20.

18 Zob. Listy Tadeusza Micińskiego do Wincentego Lutosławskiego z lat 1897-1914, s. 367, 369, 372 (listy nr 3, z 2 V 1897; nr 4, z 11 V 1897; nr 6, z początku czerwca 1897). Zob. I11 g, op. cit., s. 346. Kilka lat później z podobnym zapałem pisał T. M i c ińs ki do Miriama (Z. Przesmyckiego) o swych 
przyszedł czas, abym choć - cum terribili animae motu - sprawę przed Panem wyłożył. Oto zastanawiając się nad pracą o nieśmiertelności duszy, przyszedłem do przekonania, że musi być ona czysto sprawozdawcza i dla osobistych zacieka[wie]ń pola już nie daje. A choć samo zbliżenie do Platona już korzyścią wielką nazwać można, ale daje mi jednak o wiele mniej od tego, co mogę wyciagnąć z pracy literackiej.

Nadal wszakże przekonywał: „pracę o Platonie wykonam z wszelka pewnością później"19. Jak widać, Miciński stale zmieniał obiekty literacko-filozoficznych zainteresowań; nie kończył podjętych zadań. Przyciagało go wiele dzieł i postaci, ale jedynie przelotnie.

Inaczej wyglądał stosunek Lutosławskiego do młodego adepta filozofii platońskiej. W osobie Micińskiego dostrzegł on prawdopodobnie materiał na przyszłego ucznia i - być może - kontynuatora własnych badań nad filozofią starożytną. Początkowo zatrudnił go do pomocy przy swoich stylometrycznych kalkulacjach występowania słów w dialogach Platona ${ }^{20}$. Oczywiście, samo liczenie wyrazów nie mogło pogłębić znajomości myśli filozoficznej Platona, równocześnie więc Miciński miał czytać jego dzieła i rozpoczą pod okiem Lutosławskiego przygotowywanie doktoratu. Jak wskazuje korespondencja, Micińskiego od początku nurtowały wątpliwości co do wartości przyszłej dysertacji, spodziewał się bowiem, że jego zajęcie literackie, a nie filozoficzne, „objawi się pracą może nawet o wiele lepszą niż ta akademicka"21. Lutosławski musiał odpisać na ów list w ostrych słowach, gdyż Miciński tę odpowiedź zripostował następująco: „Wiedziałem, że filozofia platońska na wysokich szczytach przebywa, alem nie spodziewał się, że tam takie grzmoty i zachmurzenie"; nadal zapewniał o lekturze dialogów w oryginale ${ }^{22}$.

Znajomość osobista, podtrzymywana korespondencyjnie, przerodziła się w przyjaźń - jakkolwiek miała ona krótkotrwałe jedynie apogeum podczas drugiego pobytu Micińskiego u Lutosławskich ${ }^{23}$; wśród jej dowodów wymienił Pigoń nie tylko pomoc Lutosławskiego przy doktoracie, ale i jego zaangażowanie w twórczość literacką Micińskiego, którego teksty (np. dramat Walka dusz) filozof czytał, poprawiał, streszczał, a nawet po prostu przepisywał ${ }^{24}$.

Droga Micińskiego do podjęcia pracy nad doktoratem poświęconym Platonowi

studiach nad Heraklitem, którego zdania miał tłumaczyć, ale przekład ten nigdy nie ukazał się drukiem (zob. list z 3 V 1902. W: Korespondencja Tadeusza Micińskiego. Oprac. T. W ró blew s ka. „Miesięcznik Literacki” 1969, nr 11, s. 111).

19 Listy Tadeusza Micińskiego do Wincentego Lutosławskiego z lat 1897-1914, s. 374 (list nr 7, z VI 1897).

20 Zob. W. Lut o sła w s ki, The Origin and Growth of Plato's Logic: With an Account of Plato's Style and of the Chronology of His Writings. London - New York - Bombay 1897, s. 69, przypis 103. H. Struve, Logika Platona $w$ zwiazku $z$ chronologia jego pism. $Z$ powodu dzieła Wincentego Lutosławskiego "The origin and growth of Plato's Logic with an account of Plato's style and of chronology of his writings”. London. Longmans, Green and Comp. 1897, str. XVIIII i 547. „Biblioteka Warszawska" 1898, t. 2, s. 345.

21 Listy Tadeusza Micińskiego do Wincentego Lutosławskiego z lat 1897-1914, s. 374 (list nr 7).

22 Ibidem, s. 376 (list nr 9, z 16 XI 1897).

23 Zob. Sos now s ki, Playa de Mera, s. 11.

24 Pigoń, op. cit., s. 414. Zob. też Ty n e c ki Inicjacje mistyka, s. 83. Część komentarzy i poprawek dokonanych przez Lutosławskiego w dramacie Walka dusz zrekonstruował S o s n ow ski (Playa de Mera, s. 18-20). 
nie była więc prosta. Sam temat dysertacji - nieśmiertelność duszy w dialogach Platona - został zapewne zaproponowany przez Lutosławskiego, który w późnych dziełach ucznia Sokratesa odkrył pluralistyczny spirytualizm, tj. przekonanie o istnieniu wielu dusz na różnych szczeblach hierarchii duchowego rozwoju. Książka Lutosławskiego o Platonie, która podczas pobytu Micińskiego w La Corunii była już w dużej części wykończona, miała za główny przedmiot logikę Platońską, pojmowaną dość szeroko jako kompleks zagadnień teoriopoznawczych i ontologicznych. Problematyka duszy wykraczała poza obszar rozważań zawartych w owej pracy, lecz wydała się autorowi szczególnie istotna ze względów światopoglądowych. $Z$ tego wynikała potrzeba przeanalizowania zagadnienia duszy w oparciu o chronologię Dialogów, za jaką opowiadał się Lutosławski. To ambitne zadanie miał wypełnić jego świeżo pozyskany uczeń - Miciński.

Przyjrzyjmy się efektom współpracy filozofa $\mathrm{z}$ poetą, sięgając do dysertacji Micińskiego. Rozpoczął on rozprawe od wyrażenia przychylności dla ewolucyjnej wizji filozofii Platona, którą zapożyczył z pewnością od Lutosławskiego:

Chcąc pojąć poglądy Platona co do nieśmiertelności duszy, musimy przystąpić do badania jej z przekonaniem, które wynika z ogółu dotychczasowych poszukiwań, że Platon filozoficznie się rozwijał, stopniowo zdobywając prawdy oraz dowodzenia będące ostatecznym wyrazem jego myśli. [T 97 ${ }^{25}$

Autor doktoratu dzielił dialogi na trzy chronologiczne grupy: sokratyczną, „średnią” i ostatnią. O treści dialogów z epoki „średniej” pisał:

obfitość nowych teorii i dowodzeń urozmaicona jest wspaniałymi mitami przedstawiającymi nam zaświatowe krajobrazy, w świetle zaświatowych krajobrazów poetycznej imaginacji utrzymanej w karbach logicznej konsekwencji pełnym prądem płynie rzeka dowodzeń rozlewająca się częstokroć w nieprzejrzane roztocza [...]. [ T 97]

Zdanie to skomentował Lutosławski, który nie tolerował tak obrazowego stylu w rozprawie naukowej: „okropna ta rzeka! jak się rozlewa, to następuje powódź i krajobrazy znikaja, szczególniej zaświatowe!” (T 97-2)26. Jerzy Sosnowski, analizując kolejne próby ulepszenia tego fragmentu oraz uwagi filozofa, trafnie zaznaczał:

Nowy tekst nie jest wcale krótszy ani jaśniejszy od poprzedniego. Wydaje się, że Lutosławskiemu chodzi nie tyle o przejrzystość metafory, ile o samą metaforę - o fakt, że Miciński nie porzucił języka poezji2 ${ }^{27}$.

Z epoki sokratycznej Miciński krótko omówił najistotniejsze zagadnienia moralne poruszane w Eutyfronie i Apologii, gdzie „widzimy Sokratesa przed tłumami Eutyfronów, zbrojnych w powagę sądu” (T 98). Podobny charakter miał Kriton.

Skrótem T odsyłam do: Tadeusz Miciński i Platon odczytany przez młodopolskiego poetę (1897). [Oprac. T. M r ó z.] W zb.: Platon w Polsce 1800-1950. Antologia. Red. T. M ró z. Zielona Góra 2010 (wydany tu został początek rozprawy Micińskiego wraz z komentarzami Lutosławskiego). Skrót N oznacza zaś cytaty z dalszych, nieopublikowanych partii tekstu doktoratu T. Micińskiego, przywoływanych na podstawie rękopisu, datowanego 8 III 1897 (Mera): Nieśmiertelność duszy u Platona. Bibl. Narodowa, sygn. 7247. Pierwsza liczba po skrócie oznacza stronicę lub kartę, a liczba po łączniku - numer przypisu.

26 Krytykując sposób wyrażenia się Micińskiego, Lutosławski grzmiał: „Schowaj te jaskrawe metafory dla literackich czysto prac" (T 97-4).

27 Sos now ski, Playa de Mera, s. 16. 
W dialogach tych zagadnienie nieśmiertelności duszy jest jedynie wzmiankowane, najczęściej jako możliwe; w Ionie, Lachesie czy Protagorasie zaś zupełnie go brak: „wzrok nie przekracza horyzontów rzeczywistości” (T 98) - pisał Miciński. W całej zaś grupie sokratycznej nie występowały dociekania metafizyczne. O nieśmiertelności duszy jest mowa w Menonie przy okazji rozważań dotyczących źródeł wiedzy, drobne uwagi o duszy pojawiają się w Eutydemie, a następnie temat ten zostaje rozwinięty w Gorgiaszu. Jak twierdzi Miciński, nieśmiertelność duszy -

wiąże się tu [tj. w Gorgiaszu] najściślej z potrzebą idealnej moralności, a nawet zdaje się być przez tę ostatnią wywołana. Platon nie przytacza żadnych dowodów na swoje twierdzenia, a kładąc nacisk na prawdziwość podań o życiu przyszłym, używa tej prawdy jako głównej podstawy wniosku moralnego, że należy raczej zło znosić, niż je czynić. [T 101] ${ }^{28}$

Kolejne wzmianki o nieśmiertelności odnalazł Miciński w Meneksenosie i Kratylosie, w Uczcie (Miciński używa raczej tytułu Symposion lub Biesiada) natomiast wciąż brakowało argumentów za nieśmiertelnością, choć w tym dialogu odegrała ona istotną rolę w rozważaniach nad naturą ludzką:

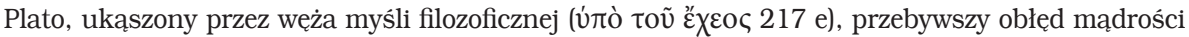

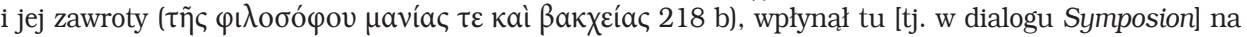
pełne i spokojne morze kontemplacji piękna. [...] I na tym odblasku wieczności polega powaga życia, w którym komedia miesza się z tragedią, a Plato, jak później Szekspir, to rozumie i tak w Symposionie ziemskie $\mathrm{z}$ boskim, a żart splata $\mathrm{z}$ religijno-nadświatowymi polotami. Pełnymi żaglami płynie on już na odkrycie nowych krain, gdzie wśród świetnej zadumy wznoszą się wieczne prawzory stworzenia, a ponad nimi swe skrzydła niezmierzone roztacza Bóstwo - czyli Jedność i Dobro. [T 105]

Zdaniem autora rozprawy, najważniejszym dialogiem był jednak Fedon. Omawiając jego treść, Miciński pisał o dowodach na nieśmiertelność duszy, które pokrótce zrekonstruował, wspominając o zastrzeżeniach, wyrażonych przez rozmówców Sokratesa. Własne zdanie oddał w następujących słowach:

Całą serię dowodów nieśmiertelności krytyka zwykle próbuje obalić i zaiste, większa część z nich przyjętą być nie może. Ale niezbitymi pozostają myśli rzucone, jakby mimochodem - że dusza organizuje ciało i nim zarządza; że nasze ciało nie jest nami. [T 108]

\section{Ten etap Platońskiego rozwoju podsumował Miciński tak:}

Widzimy, jak ogromny przedział dzieli dialog ten od poprzedzających, jakie bogactwo dowodzenia, jaka pewność nieśmiertelności go wyróżnia. W dialogach sokratycznych - Platon wątpi nawet o tradycjach religijnych; w dalszych (Menon, Gorgiasz, Kratylos) stara się tradycje te wciagnnąc do systemu swej moralności, w Symposionie rozwija nieśmiertelność gatunku, dopiero w Fedonie rzuca całe swoje światło na paradoksy naszego poznania, widzi w nich pierwiastki dane nam przed doświadczeniem (idee) oraz duszę zaznacza jako substancję, bowiem i od niej czyni zależnym rozwój i życie organizmu, ją stawia jako jedyne prawdziwe źródło naszej wiedzy o wszechświecie i czyni ją niezniszczalną. To ostatnie twierdzenie nosi już w sobie zawiązek myśli, że dusza nie jest powstałą w czasie. [T 109] ${ }^{29}$

So sn ow ski (Playa de Mera, s. 17) skomentował owe rozważania nad Gorgiaszem następująco: „[Miciński] doszedł do melancholijnej konstatacji: wiara w nieśmiertelność stanowi wprawdzie bajkę, trudno jednak ją porzucać, skoro nie posiadamy lepszej. W ten sposób Platon - zapewne nie bez zdziwienia - znalazł się w liczbie XIX-wiecznych dekadentów o pozytywistycznym rodowodzie". Jednak w świetle dalszych partii tekstu Micińskiego, zwłaszcza dotyczących Fedona, konkluzja Sosnowskiego musi upaść.

Część rozprawy poświęcona Fedonowi zyskała uznanie Lutosławskiego (T 109-79). 
Dalszy ciag rozprawy dotyczy dialogu Państwo, przy którego omawianiu Miciński skupił się na konieczności kształcenia duszy. W tej części znajduje się wiele skreśleń, akapity bywaja zamieniane miejscami, co wskazuje, że im dalszy etap w rozwoju filozoficznym Platona, tym mniej skrystalizowany jego obraz miał Miciński i - dlatego - nie potrafił ując go w strukturę rozprawy. Świadczy o tym również końcowy komentarz Lutosławskiego, doceniającego postępy, lecz akcentującego konieczność kontynuacji prac Micińskiego nad Platonem i udoskonalania samego tekstu doktoratu: „wprawiłeś się trochę, ale trzeba będzie to uważnie przerobić” (N 40).

Ostatnie karty poświęcone zostały Fajdrosowi, który ,jest filozoficznym poematem na cześć natchnienia” (N 41). W dialogu tym dopatrywał się Miciński nacisku na indywidualność duszy. Rękopis kończy się na pierwszym akapicie działu: Dialogi dialektyczne, w którym Platon miał poddawać krytyce „dotychczasowe intuicyjno-logiczne wyniki” (N 46). Odkrycie wzrastającej u Platona świadomości nieśmiertelności, a następnie indywidualizmu duszy, świadczy o tym, że Miciński zamierzał w przedstawieniu problemu rozprawy podążać za Lutosławskim. Zachowany rękopis pozwala także na spostrzeżenie, iż wykonaną przez Micińskiego pracę można uznać za ledwie przygotowawcza, to bowiem, co dla problematyki duszy było najistotniejsze, wynikało z treści późnych dialogów Platona. Do nich zaś Miciński nie dotarł. Przypuszczalnie przyczyną tego był ich charakter. Poetę mogły zniechęcić rozważania teoriopoznawcze w Teajtecie, a tym bardziej dialektyczne badania w Sofiście czy Parmenidesie. Krótko mówiąc, tam, gdzie przestał dochodzić do głosu Platon-poeta, zakończyło się zainteresowanie Micińskiego Platonizmem. Powodem odstapienia Micińskiego od doktoratu nie był brak racjonalnej argumentacji u Platona, ale raczej jej nadmiar w dialogach późniejszych. Niewątpliwie jednak trzeba się zgodzić z Sosnowskim, iż w tym wypadku „literatura wygrywa ostatecznie $z$ filozofią"30.

Promotor wielokrotnie nanosił uwagi mające zdyscyplinować doktoranta: domagał się wprowadzenia cytatów, dokładnego ich lokalizowania - z użyciem numeru stronicy i litery z wydania Stephanusa (np.: „Cytujże, bo inaczej to robi wrażenie blagil”, T 98-1131), podkreślał, że koniecznie należy ograniczyć streszczanie dialogów, zwłaszcza tych, które do głównego zagadnienia niewiele wnosiły, jak Meneksenos czy Kratylos (T 102-51; 103-62), krytykował szafowanie wielokropkiem, uznając to za cechę właściwą pisarstwu „niejasnych umysłów” (T 104-67). Napominał: „nie nadużywaj imienia Pana Boga ani terminów filozoficznych” (T 109-78). Kilkukrotnie odsyłał Micińskiego do własnych prac jako do wzoru warsztatu naukowego: „Przeczytajże sobie, do kroćset szatanów, milion razy $O 1^{\text {ch }} 3^{\text {ch }} 4^{\text {ach }}$, żeby się nauczyć cytowania!” (T 103-60) ${ }^{32}$.

Oprócz przygotowywania rozprawy Miciński podejmował próby translatorskie. Przełożył np. większą część końcowego mitu z Gorgiasza (523 a - 525 c). Przytoczmy go:

30 Sosnows ki, Playa de Mera, s. 20.

31 Część wykreślonych fragmentów z rękopisu i innych uwag Lutosławskiego podaje S o s n o w s ki (ibidem, s. 16-17).

32 Lutosławski tak enigmatycznie zapisał tytuł swojej rozprawy: O pierwszych trzech tetralogiach dzieł Platona („Rozprawy Akademii Umiejętności. Wydział Filologiczny”. Seria 2. T. $11\langle 1898\rangle$ ). 
Posłuchaj zatem pięknego bardzo opowiadania, które ty uznasz przypuszczalnie za baśń, a ja - za coś głębszego. I dlatego ci podam jako prawdę. Homer twierdzi, że Zeus, Posejdon i Pluton podzielili się władza, otrzymaną po ojcu. A było za czasów Kronosa prawo dla ludzi, teraz i na wieki u bogów trwające: człowiek sprawiedliwie i święcie żyjący odchodzi po śmierci na wyspy błogosławionych i tam w pełnym szczęściu, wolny od trosk zamieszkuje, zaś niesprawiedliwy i bezbożny - idzie do ciemnicy, zwanej Tartarem - na pokutę i ukaranie. Pod rządami Kronosa i w początkach Zeusa sądzili żyjący żywych - tegoż dnia, kiedy ci ostatni mieli umrzeć. Stąd wyroki wypadały źle. Pluton więc i dozorcy wysp błogosławionych poszli i poskarżyli się Zeusowi, że do obu miejsc napędzają im ludzi nieodpowiednich. I odrzekł Zeus: „Zaiste, ukrócę te zajścia. Sprawy sądzone są źle, gdyż oskarżeni stają przed sądem w powłoce, jako iż są żywi. I wielu - mówił - mających dusze nikczemne - ustrojeni są w ciała piękne, rodowe tytuły i bogactwa, a podczas badań śledczych mają na swe usługi licznych świadków, dowodzących ich życia chwalebnego. Sędziowie podlegają wpływom, będąc na domiar sami okryci, a duszę mając powleczoną w bryłę cielesną, posługując się wzrokiem i słuchem. To wszystko staje im na przeszkodzie - ich własne oraz podsądnych powłoki. Najpierwej trzeba im odebrać wiedzę o dniu skonania, co znają teraz naprzód. Przeto Prometej odebrał rozkaz, aby ich tej właściwości pozbyć. Po wtóre, należy sądzić ich nagie dusze - czyli zmarłych. Sędzia winien być też bez odzieży - umarły - i duszą patrzeć w duszę tego, którego śmierć wzięła nagle - pozbawionego wszelkich przywilejów i ziemskich ornamentów, aby sąd był sprawiedliwy. Ja poznawszy to pierwej niżeli wy - naznaczyłem sędziami synów moich - dwóch z Azji: Minosa i Radamanta, jednego z Europy - Eaka. Po śmierci będą oni sądzili na błoniu, gdzie trzy drogi się krzyżuja, a dwie $\mathrm{z}$ nich prowadzą: ta na wyspy błogosławionych, owa do Tartaru. Radamant sądzić będzie mieszkańców Azji, Eak zaś - Europy. Minosowi dam przewodnictwo i głos rozstrzygający, gdy ci dwaj będą w jakiejś wątpliwości. Aby wyroki ludzkich wędrówek były jak najbardziej trafne". Oto co, Kalliklesie, słyszałem i czemu wiarę daję, a z opowiadań tych wyciagam taki wniosek: śmierć jest, jak sądzę, niczym innym, jak rozdziałem dwojga rzeczy od siebie: duszy i ciała. Gdy się zaś rozdzieliły - każde $z$ nich zachowuje stan swój niewiele gorzej, jak kiedy człowiek żył: ciało zachowuje widocznymi swe właściwości naturalne i pozyskane oraz ślady stanów przeszłych; (następuje bliższe rozwinięcie tej myśli)... W duszy, obnażonej z ciała, przejrzystymi się staja - jej charakter i wrażenia, jakie otrzymał człowiek zależnie od rodzaju swoich zajęć. Gdy zatem przychodzą przed swego sędzię - Azjaci przed Radamanta, wówczas on przywołując, ogląda duszę każdego, nie wiedząc czyja, i często mając przed sobą duszę króla perskiego lub innego mocarza, nie dostrzegał w niej nic zdrowego, lecz zbiczowaną i owrzodziałą od przewrotności oraz krzywd, które każdy postępek wyrył na duszy, wszystko skrzywione przez pychę i kłamstwo, prostoty brak z powodu niekarmienia się prawdą; i widział ją napełnioną samowolą, bezwstydem, pychą, nieokiełznaniem postępowania nieforemną i ohydną. I tę bez czci odesłał wprost do ciemnicy, gdzie ją czekają [!] wycierpieć odpowiednie męki. A każdy skazaniec, uciśnięty przez sprawiedliwość, cierpiący słuszną karę, ma się poprawić i zyskać lub stać się przykładem dla innych, by widząc, jakie znosi cierpienia, stali się lepszymi. Odnoszą zaś pożytek i pokutę przed bogami i ludźmi sprawują ci, których grzechy są wyleczalne. Jednak zarówno tutaj, jak w Hadesie zbawienie przychodzi przez ból i cierpienie - inaczej win swych pozbyć się nie można. [N 2-7]

Zacytowany tekst jest zaledwie szkicem, pierwszą wersją, pozostawiająca mniej jasne w odbiorze wyrażenia do późniejszego opracowania. Już sam wybór fragmentu do tłumaczenia wskazuje na większe zainteresowanie poety sferą mitologiczną, obrazową dialogu niż jego treściami ściśle filozoficznymi, etycznymi. Losy duszy w zaświatach, sąd nad duszami, w egzotycznej scenerii dokonywany przez bogów, musiały oddziałać na wyobraźnię poety dużo silniej od dialektycznych poszukiwań. Bardzo prawdopodobne, że zaprezentowany przekład jest pierwszą w ogóle próbą translatorską Micińskiego, zatem stanowi cenne świadectwo jego skromnego dorobku w tej dziedzinie, co uzasadnia przytoczenie tego obszernego cytatu in extenso ${ }^{33}$. Miciński przejął od Lutosławskiego chronologię dialogów Platona, całą wizję 
przemian jego filozofii, twierdził bowiem nawet - powtarzając za swym mistrzem - iż Teajtet to krytyka czystego rozumu w rozwoju Platonizmu (T 97). Że Miciński zżył się z interpretacją Platona dokonana przez Lutosławskiego, świadczą również wyrzuty, jakie mu czynił, dotyczące jego apodyktyczności:

Ty skonstruowałeś sobie gmach czysto logiczny na sposób Platoński, ale czyż sam Platon nie zmieniał się i czy nie czuć burzy przebytej między Biesiadą a Prawami albo Parmenidesem i Teetetem a poprzednimi dialogami ${ }^{34}$

Z tej apodyktyczności wynikały zapewne problemy filozofa w obcowaniu z ludźmi, także bliskimi, którzy boleśnie musieli odczuwać jego bezwzględne niekiedy słowa i czyny. Miciński odwoływał się do owej ewolucyjnej interpretacji Platonizmu, apelując do Lutosławskiego o większą - wzorem Platona - gotowość do zmian w jego podejściu do ludzi.

Oprócz niewątpliwego wpływu znajomości filozofii Platona na twórczość literacką Micińskiego powracały jeszcze również w jego biografii epizody „platońskie”. Wiadomo np. o wykładzie o Platonie dla uczniów chrześcijańskiej szkoły gospodarczej, jaki Miciński wygłosił, przebywając u wuja swej żony w Bakłani. Informował o tym Lutosławskiego: „głównie podnosiłem poszukiwanie dowodów nieśmiertelności duszy w celach odrodzenia ojczyzny i ludzkości oraz wysokie pojęcie miłości”35.

Lutosławski, co oczywiste, przyczynę niepowodzenia projektu dysertacji o Platonie widział w brakach doktoranta, o którym pisał - już po jego śmierci:

Miciński nie był artystą. Godzi się $z$ innej strony zaznaczyć, że jeszcze mniej był myślicielem. Nie miał ani wykształcenia potrzebnego, ani wyszkolenia myśli, ani tej wybredności, która odróżnia to, co ważne, od tego, co błahe, i przez to uwypukla kontury rzeczywistości. Więc kim był Miciński? Marzycielem tęskniącym do wiedzy, a niezdolnym do jej wytrwałego zdobywania, nastrojowcem ulegającym zbyt zmiennym nastrojom, literatem chwytającym zbyt liczne tematy, aby dobrze opracować jedno arcydzieło $^{36}$.

W autobiografii skreślił zaś następującą charakterystykę literackiego warsztatu Micińskiego:

był on [tj. Miciński] niedostępny dla metafizyki, choć ustawicznie do niej dążył; szukał prawdy nie tam, gdzie należy, i nie znalazł jej aż do śmierci. Jego pociagały nadzwyczajne różne przeżycia i brał na serio literaturę okultystyczną, a nie miał cierpliwości, aby poważnie zbadać pisma prawdziwie twórczych filozofów. [...]

datując prace translatorskie nad nimi na okres pobytu w Hiszpanii lub krótko po powrocie stamtąd. Zob. też s. 175.

Listy Tadeusza Micińskiego do Wincentego Lutosławskiego z lat 1897-1914, s. 391 (list nr 20, wiosna 1899).

Ibidem, s. 387 (list nr 17, z 3/15 XII 1898). Miciński wygłosił tam również drugi wykład - o Mickiewiczu - i swoje emocje z tym związane tak opisał w liście do Lutosławskiego (ibidem, s. 376 〈list nr 17, z listopada 1897)): „byłem jak Sokrates w Fedrze i sam tłumiąc wzruszenie, patrzyłem na łzy niektórych słuchaczów”, myląc zresztą Fajdrosa z Fedonem. Wspomniana przez Micińskiego szkoła stanowiła w istocie wspólnote pracy, bractwo quasi-religijne, założone przez rosyjskiego arystokratę N. Nieplujewa, co poeta przemilczał w liście, spodziewając się - być może - ostrej reakcji filozofa (zob. Ty n e cki, Inicjacje mistyka, s. 169-176. - I11 g, op. cit., s. 355).

36 W. Lu to sła w s k i, Lucyferyzm Tadeusza Micińskiego. „Tygodnik Illustrowany” 1931, nr 44, s. 832. Dalej autor wspomnienia pisał też, że do opracowania własnego systemu filozofii pobudziło go pragnienie wiedzy Micińskiego, któremu wykładał ów system podezas jego pobytu w Hiszpanii. 
Miał wygórowaną ambicję, graniczącą z megalomanią [...]. On chciał pisać inaczej niż wszyscy i tym czytelników zadziwiać.

Lubił cytować licznych autorów, których nie doczytał i nie zrozumiał, aby się popisywać erudycją [...]. U Micińskiego pozory erudycji przygnębiają biednych czytelników, którzy nie są w stanie sprawdzić cytat, lecz rozśmieszają takiego czytelnika, co zna cytowane pisma i łatwo spostrzega, jak lekkomyślnie Miciński cytuje ${ }^{37}$.

Słusznie zapewne Pigoń przypuszcza, że w słowach tych zawarty jest odwet za odmalowanie Lutosławskiego jako barona de Mangro w Nietocie, a także w innych dziełach Micińskiego ${ }^{38}$. Niewykluczone, iż poeta cierpiał z powodu jakiegoś kompleksu Lutosławskiego. Nie można też zlekceważyć sprawy zaaranżowania małżeństwa Micińskiego. Pogłębione konfliktem osobistym i ideowym niedopasowanie dwóch indywidualności, które postawiły sobie za cel doprowadzenie do powstania pracy o nieśmiertelności duszy u Platona, skazało całe to przedsięwzięcie na klęskę już u jego zarania. Przyjaźń przerodziła się w rozżalenie, a nawet w pogardę. Nie wydaje się całkowicie słuszne zdanie Tyneckiego, że „zarzuty Lutosławskiego czynione sa metodą "przyganiał kocioł garnkowi", a wszystko, co Lutosławski pisał o Micińskim, jest krętacze"39. Przyznać jednak trzeba, iż samo sformułowanie ostrego i krytycznego sądu o Micińskim nie nastąpiło dopiero po zapoznaniu się Lutosławskiego $z$ dziełami literackimi jego niedoszłego doktoranta. Wyrok o Micińskim jako literacie - delikatnie mówiąc - poszukującym filozoficznych natchnien bez konieczności dogłębnych studiów filozoficznych, wypracowującym własny, oryginalny styl, został przez filozofa wydany już w Hiszpanii, podczas czytania i komentowania platońskich prób poety. Stworzenie przez Micińskiego postaci literackich karykaturujących Lutosławskiego zmieniło jedynie tyle, że filozof wyrobioną przed laty opinię zaczął wyrażać głośno, nie ograniczając się już do prywatnych notatek. Określenie tej reakcji „odwetem” wydaje się chyba zbyt mocne, zwłaszcza że w ocenach Lutosławskiego nie był Pigoń obiektywny, mając w pamięci własne z nim spotkania i losy stowarzyszenia Eleusis ${ }^{40}$.

Na koniec warto przyjrzeć się kwestii wpływu znajomości Platona na twórczość literacką Micińskiego. Wątki oniryczne w jego poezji, jak podkreślał Tadeusz Linkner, wiązały się ściśle $z$ Platońską anamneza, a z pojęciem tym Miciński zapoznał się właśnie pisząc rozprawę o Platonie. Wniosek Linknera wypływa jednak m.in. $\mathrm{z}$ błędnej lektury rękopisu Nieśmiertelności duszy u Platona. Anamneza w PlatońBydgoszcz 2004, s. 54, 68-69.

Ty n e cki, Inicjacje mistyka, s. 318, przypis 40. Autor podaje, że na temat erudycji Micińskiego ironicznie wypowiadał się także S. Witkiewicz. Podejrzenia budziła również jakość erudycji mistycznej zarówno Lutosławskiego, jak i Micińskiego - zob. J. A. H e r b a c z e w s k i, „I nie wódź nas na pokuszenie..." Szkicowane wizerunki dusz wspótcześnie wybitnych na tle myśli dziejowej. Kraków 1911 , s. 133.

40 S. Pigoń, Z Komborni $w$ świat. Wspomnienia młodości. Przedm. F. Buja k. Kraków 1946, s. 182-229. Zob. też Mróz, Wincenty Lutosławski 1863-1954, s. 246-247. 
skim Menonie, którego fragmenty (zwłaszcza 85 c-d) komentował Miciński, nie jest wynikiem snu, ale do przebudzenia się ze snu Sokrates porównuje posiadanie i przypomnienie sobie wiedzy geometrycznej przez badanego przez siebie niewolnika. Znajomość geometrii została więc niejako przebudzona przez Sokratesa. Miciński nie napisał, jak podaje Linkner: „Wiedzy tej posiąść 〈człowiek〉 nie mógł w tym życiu, zatem miał ją w śnieniu, gdy nie był człowiekiem" ${ }^{41}$. Właściwe odczytanie tego zdania $z$ doktoratu powinno brzmieć: „Wiedzy tej posiąść ni kt nie mógł w tym życiu, zatem miał ją w in ny m, gdy nie był człowiekiem" (T 99; podkreśl. T. M. ${ }^{42}$, co jest zgodne $z$ dalszym ciagiem dialogu (85 e - 86 a). Linkner stwierdził:

Ponieważ ze snem wiele w tych rozważaniach o Platonie mu [tj. Micińskiemu] się kojarzyło, więc zaraz dalej powiadał:

Kto wie, czy życie nie jest zaśnięciem.

A zaśnięcie - życiem? [... $]^{43}$

Przywołany tu wyimek $\mathrm{z}$ rękopisu Micińskiego stanowi w istocie parafrazę z Gorgiasza, gdzie Sokrates słowami Eurypidesa wspierał swoją polemikę z Kalliklesem, chcąc mu wykazać, że immoralizm - polegający na zaspokajaniu pragnień przez silne jednostki - prowadzi do życia, które w istocie jest śmiercią. Cytat ten został jednak przez Micińskiego przełożony błędnie, gdyż zamiast „zaśnięciem” powinno znajdować się tam „umieraniem” (492 e), co zresztą wytknął poecie Lutosławski ${ }^{44}$. Dalej wszakże Miciński (T 101) podawał tekst zgodnie z Platonem: „I być może naprawdę umarliśmy!" (493 a).

Na poparcie swojej tezy Linkner przywołał kilka fragmentów dzieł Micińskiego, w których jednak anamneza przyjęła inne niż u Platona znaczenie - polega ona u Micińskiego na przypomnieniu sobie poprzednich żywotów. Jej celem nie jest zatem zdobycie wiedzy o wiecznym przedmiocie, ale informacji o wcieleniach duszy i jako taka może być po prostu utożsamiona $z$ metempsychoza; do wyjaśnienia źródeł tak rozumianej anamnezy wystarczyłaby inspiracja Królem Duchem Słowackiego, na co nie wprost wskazywała Halina Floryńska ${ }^{45}$. Miciński przejął więc od Platona samo pojęcie anamnezy, lecz jego treść była zasadniczo odmienna. Podobieństwo może tu zasadzać się jedynie na tym, że u Platona i u Micińskiego anamneza jest uświadomieniem, przypomnieniem tego, co zapomniane. U Micińskiego wszakże przypomnienie to nie przebiega w formie racjonalnej, ale przez ,anamnetyczny trans”, odkrywanie warstw osobowości, podświadomości, w psychodramie

41 T. Li n k n e r, Zanim skończyło się maskarada. Ze studiów nad twórczościa Tadeusza Micińskiego. Gdańsk 2003, s. 225. Podkreśl. T. M.

42 Zob. też N 15. Miciński zgodnie z ówczesnymi zasadami napisał „w innem”, co mogło doprowadzić do błędnego odczytania.

43 Linkner, op. cit., s. 225.

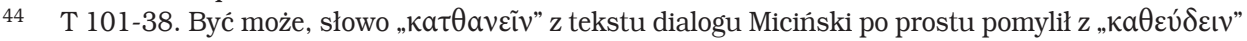

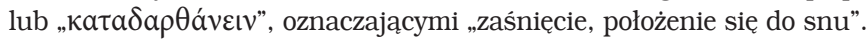

45 H. Floryń ska, Spadkobiercy Króla Ducha. O recepcji filozofii Stowackiego $w$ światopogladzie polskiego modernizmu. Wrocław 1976, s. 94, 144-149. Platońskich źródeł metempsychozy w twórczości Micińskiego dopatruje się B. Si e n ki e w i c z (Micińskiego sny - „ruiny tajemnicze”. W zb.: Poezja Tadeusza Micińskiego. Interpretacje. Red. A. C zaba n ow s ka - W rób el, P. Pró c hniak, M. Sta la. Kraków 2004, s. 89-91, 94-96). 
czy autohipnozie; łączy się to też ze swoista podróżą w czasie ${ }^{46}$. To treści zdecydowanie obce anamnezie Platońskiej. Samo słowo brzmiało jednak w tekstach Micińskiego wystarczająco egzotycznie, by zrobić na czytelniku wrażenie „wtajemniczenia” autora.

Andrzej Nowicki, szukając źródeł inspiracji Micińskiego, sporządził rejestr przywoływanych przez poetę filozofów, w którym - rzecz jasna - znalazł się też Platon. Na poetyckie filozofowanie Micińskiego większy wpływ wywarli jednak inni wymienieni na tej liście. Nowicki zastrzegał przy tym:

pojęcie „źródeł inspiracji” może wprowadzać w błąd. Trafniejsze byłoby przyjęcie, że Miciński zwrócił uwagę na wymienionych myślicieli, ponieważ znajdował u nich „affinity” - rodzaj duchowego pokrewieństwa $\mathrm{z}$ własną postawą, własnym sposobem myślenia ${ }^{47}$.

Swoją wiedzę na temat Platona czerpał Miciński - prócz wybranych dialogów - także z książek Édouarda Schuré i Karla du Prela, które należały do jego ulubionych lektur ${ }^{48}$. Świadczyło to niewatpliwie o jego fascynacji mistycyzmem i ezoteryką. Pierwszy z tych autorów traktował Platona jako kontynuatora tradycji ezoterycznej i pisał o nim, że „idzie za Pitagorasem, jak niosący pochodnię na misteriach eleuzyjskich kroczył za wielkim hierofantem"49. Drugi uważał Platona za mistyka, wedle którego człowiek to „ucieleśniona postać transcendentalnej jaźni” ${ }^{50}$, i rozpatrywał jego filozofię w kontekście misteriów i religii greckiej.

Platon, odczytywany zwłaszcza jako mistyk i metafizyk, mógłby rzeczywiście być - i bywał - inspiracją dla młodopolskiej poezji ${ }^{51}$. W przypadku Micińskiego, co było wyjątkowe, fascynacja filozofią Platońską miała głębsze, bezpośrednie podstawy w postaci podjętej próby potraktowania jej jako przedmiotu badań naukowych. Pozornie sprawia to zatem wrażenie czegoś więcej niż jedynie zachwycenia poetyckiego, ale gdy już Micińskiemu w Platonie zabrakło poezji, stracił dla niego zainteresowanie.

Próbę przetworzenia i zsyntetyzowania inspiracji filozoficznych przez Micińskie-

Zob. Lin kn e r, op. cit., s. 235-254. Inne przypadkowe zbieżności z Platonem wskazały M. P o d raza-Kwiatkowska (Przedranna epifania Tadeusza Micińskiego. 〈O wierszu „Juź świt...”). W zb.: jw., s. 15) i Sienki ew icz (op. cit., s. 73-76, 80-81, 86-87, 92). Na ogół jednak trudno rozpatrywać te przypadki w kategoriach wpływu.

47 A. Nowi c ki, Tadeusza Micińskiego subiektywizacja i pluralizacja lucyferyzmu. W: T. Mi c i ń s k i, Nietota. Księga tajemna Tatr. Warszawa 2004, s. 371. Nowicki, stosując znaleziony u Micińskiego angielski termin „affinity”, nie potrafił wskazać, skąd poeta go zaczerpnął, odniósł go natomiast do affinitas z myśli renesansowej. Jakkolwiek racja jest, że Miciński - mimo wpływu, jaki wywierał nań promotor niedoszłego doktoratu - „nie przejął wprawdzie poglądów Lutosławskiego” (s. 368), to wydaje się, że źródeł pojęcia affinity, właśnie w jego wersji angielskiej, należy poszukiwać u Lutosławskiego, w jego bowiem książce o Platonie, którą Miciński znał, jednym z kluczowych terminów jest „stylistic affinity”, czyli zbieżność, powinowactwo stylistyczne poszczególnych dialogów Platona. Zob. Lin kn e r, op. cit., s. 340-341. Zob. też A. J o c z, Przypadek „osy rozbójniczej”. Rozważania o gnostycyzmie i neognozie $w$ literaturze polskiej przełomu XIX i XX wieku. Poznań 2009, s. 69-71, 98-101.

E. Schuré, Wielcy wtajemniczeni. T. 2. Warszawa 1995, s. 132.

K. du Pre1, Mistyka starożytnych Greków. Przeł. J. Kretz. Lwów b.r., s. 75.

Zob. M. Podraza-Kwi a t k ow s ka, Młodopolskie doświadczenie transcendencji. W zb.: Stulecie Młodej Polski, s. 109-117. 
go ocenił Jerzy Tynecki następująco: „okaże się ona zlepkiem - tworzonym często pro domo sua - najróżnorodniejszych, często nie pierwszego gatunku systemów filozoficznych", których nie można potraktować jako kryterium oceny twórczości poety $^{52}$. Trudno więc jednoznacznie uznać Platona za inspirację dla dzieł Micińskiego, nawet dla wątków tak - wydawałoby się - źródłowo bezsprzecznie Platońskich jak anamneza. Poeta prawdopodobnie czerpał wiedzę o niej wprost $z$ dialogów ${ }^{53}$, ale wykorzystując to pojęcie w swej twórczości, tak mocno je przekształcił, że ledwie przypominało ono swój Platoński oryginał. Pozostało właściwie tylko wspólne słowo. Zdarza się to zresztą w recepcji poetyckiej nader często, że nawet przy powoływaniu się wprost na Platona dokonywane są na materii Platońskiej przetworzenia idące tak daleko, że nie pozwalają na jednoznaczne oddzielenie śladów koncepcji Platona od romantyzmu czy mistycyzmu przełomu wieków ani na stwierdzenie oryginalności i źródłowego charakteru Platońskiej inspiracji.

Podsumowując doktorat Micińskiego, wypada zauważyć, że z powodu konfliktów osobistych i niemożności poddania się przez autora rygorom naukowym, a także na skutek niezaakceptowania pasji literackich doktoranta przez niedoszłego promotora nie udało się doprowadzić do ukończenia rozprawy. Konsekwencją zniechęcenia Micińskiego do Lutosławskiego stało się zarzucenie pracy nad Platonem, którego twórczość dojrzała, dialektyczna, bogata filozoficznie, nie miała już dla Micińskiego początkowego poetyckiego i mitologicznego powabu.

Lutosławski też zapewne rozczarował się poetą, który nie spełnił jego oczekiwań jako autor rozprawy doktorskiej kontynuującej i rozwijającej badania opiekuna: „Filozof chce mieć za ucznia filozofa, a nie literata” ${ }^{4}$. Na ucznia, który dzieliłby pasje Lutosławskiego, musiał on czekać niemal trzy dekady. Dopiero podczas zatrudnienia Lutosławskiego w Uniwersytecie Stefana Batorego w Wilnie w okresie międzywojennym został napisany i z sukcesem obroniony doktorat $O$ rozwoju pogladu Platona na duszę ${ }^{55}$. Jego autorem był Benedykt Woyczyński, znakomicie zapowiadajacy się młody badacz, filolog i historyk filozofii, którego karierę przekreśliła przedwczesna śmierć. Dysertacja Woyczyńskiego stanowiła spóźnioną realizacje planu i nadziei Lutosławskiego, powstała pod jego kierunkiem, na podstawie

J. Ty n e ki, Tadeusz Miciński. Młodość - początki literackie. „Prace Polonistyczne” 1960, s. 182. Pisał o tym także E. Ku źm a (Oksymoron jako gest semantyczny $w$ twórczości Tadeusza Micińskiego. W zb.: Studia o Tadeuszu Micińskim, s. 196): „Wchłonął Miciński całą tradycję monistycznej filozofii, chociaż wydaje się, że wiedza o niej nigdy nie była systematyczna ani głęboka”. Synkretyzm Micińskiego w sferze religijnej, kulturowej, gatunkowej, posunięty aż do deformacji, uczyniła kluczem interpretacyjnym C. S u s z k a (W poszukiwaniu utraconej jedni. O synkretyzmie kulturowo-religijnym $w$ twórczości Tadeusza Micińskiego. „Ruch Literacki” 2001, z. 2). Zob. też Sienkiewicz, op. cit., s. 86.

53 Sienkiewicz (op. cit., s. 99-102), uważając, że preegzystencja, anamneza i metempsychoza u Micińskiego mają swe źródło w filozofii Platona, uzasadnia ten fakt znajomością jego dialogów i cytuje przywoływany tu już list Micińskiego do Lutosławskiego, w którym poeta deklarował lekturę większości dialogów w języku greckim, ale pomija milczeniem dopisek Lutosławskiego, że były to ledwie cztery $\mathrm{z}$ nich.

55 Rozprawa ta została wydana stosunkowo niedawno w opracowaniu naukowym $Z$. Nerczuka i J. P a w laka: B. W o y c zy ń s ki, O rozwoju poglądu Platona na duszę. Toruń 2000. 
opracowanej przez niego chronologii dialogów, podejmowała i rozwijała jego wnioski dotyczące Platońskiej koncepcji duszy.

Miciński - istotnie - filozofem nie był. Gdyby jednak Lutosławski zdołał zachęcić go do tłumaczenia dialogów, oddaliby obaj kulturze polskiej znaczną przysługę, ponieważ wydaje się, że Miciński dysponował dość dobrym warsztatem translatorskim, który pozwalał mieć nadzieję na zwieńczenie sukcesem kilku przynajmniej przekładów. Mogłoby to stanowić udane połączenie literackiego powołania Micińskiego z materią filozoficzną, Platońską. Niestety, tak się nie stało.

\footnotetext{
Abstract

TOMASZ MRÓZ University of Zielona Góra

\section{TADEUSZ MICIŃSKI'S UNFINISHED DOCTORAL DISSERTATION ON SOUL IMMORTALITY IN PLATO'S PHILOSOPHY}

The subject of the article is a dissertation by Tadeusz Miciński who attempted to obtain the degree of doctor of philosophy under supervision of a philosopher Wincenty Lutosławski, a worldwide famous Plato's dialogues scholar. The thesis referred to the problem of soul immortality and was never completed. The remaining handwritten fragments are initial parts of the dissertation and include the supervisor's remarks and translations of small excerpts of Dialogues done for the purpose of the paper. The article presents the history of a complex relationship between Lutosławski and Miciński, consisting of, inter alia, Miciński's help in Lutosławski's language statistics calculations, and subsequent Lutosławski's criticism of Micinski's poetry. The analysis of the available handwritten fragments allows for a revision and specification of some of the opinions on Miciński's translational history effects and Platonic inspirations in his poetry.
} 